\title{
Zinc Supplementation Selectively Decreases Fetal Hepatocyte DNA Synthesis and Insulin-Like Growth Factor II Gene Expression in Primary Culture
}

\author{
SUSAN F. TOWNSEND, KAREN K. BRIGGS, NANCY F. KREBS, AND K. MICHAEL HAMBIDGE \\ Department of Pediatrics and Center for Human Nutrition, University of Colorado Health Sciences Center, \\ Denver, Colorado 80262
}

\begin{abstract}
Zinc is important for normal cell growth and differentiation, DNA synthesis, and gene expression. IGFII is a fetal growth and differentiation factor whose regulation is largely unknown. To assess the effect of zinc $(\mathrm{Zn})$ on fetal hepatocyte IGF-II expression and DNA synthesis, primary cultures of ovine fetal hepatocytes were studied in serum-free medium containing $1 \mu \mathrm{mol} / \mathrm{L} \mathrm{Zn}$ or supplemented to 10 or $50 \mu \mathrm{mol} / \mathrm{L} \mathrm{Zn}$. Fetal hepatocyte DNA synthesis, $\mathrm{Zn}$ and protein content, IGF-II $\mathrm{mRNA}$, and IGF binding protein production were measured. $\mathrm{Zn}$ concentration in medium increased slightly in unsupplemented dishes, from 1 to $1.5 \mu \mathrm{mol} / \mathrm{L}$; however, $\mathrm{Zn}$ concentration declined by 4 and $8 \mu \mathrm{mol} / \mathrm{L}$ over $24 \mathrm{~h}$ in culture medium supplemented to contain either 10 or $50 \mu \mathrm{mol} / \mathrm{L} \mathrm{Zn}(p<$ $0.05)$. $\mathrm{Zn}$ content of cell pellets increased 155 and $204 \%$ after $24 \mathrm{~h}$ in supplemented cultures compared with unsupplemented controls, demonstrating uptake of $\mathrm{Zn}$ by the liver cells. Media $\mathrm{Zn}$ supplementation to 10 and $50 \mu \mathrm{mol} /$ $\mathrm{L}$ decreased ${ }^{3} \mathrm{H}$-thymidine incorporation of cells in culture by 11 and 13\%, respectively, compared with $1 \mu \mathrm{mol} / \mathrm{L} \mathrm{Zn}$ $(p=0.001)$. Addition of $\mathrm{Zn}$ caused a progressive 2- to 3fold decline in the nuclear labeling index of fetal hepatocytes, whereas the labeling index of nonhepatocytes increased almost 2-fold at $50 \mu \mathrm{mol} / \mathrm{L}$ compared with $1 \mu \mathrm{mol} /$ L Zn. Associated with decreased hepatocyte DNA synthesis, IGF-II mRNA abundance declined by almost $30 \%$. IGF binding protein content of conditioned medium did not change with added $\mathrm{Zn}$. Cellular DNA and protein contents did not vary after $24 \mathrm{~h}$ in culture with either 1,10 , or 50 $\mu \mathrm{mol} / \mathrm{L} \mathrm{Zn}$, suggesting that $\mathrm{Zn}$ was not toxic to the cells. We conclude that $\mathrm{Zn}$ selectively decreases fetal hepatocyte proliferation in primary culture, whereas nonparenchymal cell growth is not inhibited. Some of this response may be caused by decreased expression of IGF-II, an autocrine growth factor for fetal hepatocytes. (Pediatr Res 35: 404$408,1994)$
\end{abstract}

\section{Abbreviations}

Zn, zinc

IGFBP, IGF binding protein

Received March 1, 1993; accepted November 17, 1993.

Correspondence and reprint requests: Susan F. Townsend, M.D., Assistant Professor of Pediatrics, University of Colorado Health Sciences Center, B-195, 4200 E. 9th Ave., Denver, CO 80262.

Supported by grants P30 HD27827, DK12432, and RR69 from the National Institutes of Health and by the Bristol-Myers Squibb Mead-Johnson Nutrition Research Grant Program.
Adequate $\mathrm{Zn}$ supply to the fetus is essential for normal growth $(1,2)$. However, the pathways in which $\mathrm{Zn}$ plays a role in fetal growth regulation are largely unknown. Nonetheless, the liver is thought to be a major site of $\mathrm{Zn}$ metabolism in the fetus, as it is in the newborn animal $(1,2)$. $\mathrm{Zn}$ is an important cofactor for DNA synthesis and gene transcription $(2,3)$, and $\mathrm{Zn}$ deficiency may affect growth in part through decreased DNA synthesis and RNA production.

The fetal liver plays a central role in many fetal metabolic pathways and is a source of circulating growth factors and regulatory proteins, such as IGF-II and IGFBP. IGF-II is a peptide hormone with structural homology to proinsulin whose importance in fetal growth regulation has recently been established (4). The IGFBP are a family of proteins that specifically bind IGF and regulate their biologic activity (5). Zn deficiency has been associated with decreases in a structurally and functionally related growth factor, IGF-I, in lambs and rats $(6,7)$. The effects of $\mathrm{Zn}$ on fetal IGF or IGFBP production have not been examined previously. To investigate the role of $\mathrm{Zn}$ in regulation of fetal liver cell IGF-II gene expression, IGF-BP biosynthesis, and DNA synthesis, we studied ovine fetal hepatocytes maintained in primary culture in medium containing minimal $\mathrm{Zn}$ ( 1 $\mu \mathrm{mol} / \mathrm{L})$, physiologic $\mathrm{Zn}(10 \mu \mathrm{mol} / \mathrm{L})$, and excess $\mathrm{Zn}(50$ $\mu \mathrm{mol} / \mathrm{L})$.

\section{MATERIALS AND METHODS}

Hepatocyte isolation and culture. Hepatocytes were isolated by in situ perfusion and collagenase digestion from late gestation Columbia-Rambouillet fetal sheep $(131 \pm 3 \mathrm{~d}$ gestation, term $=$ $145 \mathrm{~d}$ ) and cultured as described (8). All protocols were approved by the Animal Care and Use Committee of the University of Colorado Health Sciences Center. After hepatocyte isolation, cells were suspended in attachment medium (arginine-free $\alpha$ minimum essential medium, with $1.1 \mathrm{mM}$ glucose, $2 \mathrm{mM}$ lactate, $0.4 \mathrm{mM}$ ornithine, $10 \% \mathrm{FCS}, 1 \times 10^{4} \mathrm{IU} / \mathrm{L}$ penicillin, $100 \mathrm{mg} /$ L streptomycin, and $50 \mathrm{mg} / \mathrm{L}$ kanamycin) and plated at $8 \times 10^{6}$ cells/100-mm dish. Liver cells were allowed to adhere to dishes overnight in humidified air: $\mathrm{CO}_{2}(19: 1)$ at $37^{\circ} \mathrm{C}$. The medium was then changed to serum-free $\alpha$-minimum essential medium, with $0.2 \% \mathrm{BSA}$, and either no additional $\mathrm{Zn}$ or addition of $\mathrm{ZnSO}_{4}$ stock solution $(1000 \mathrm{~g} \mathrm{Zn} / \mathrm{L})$ to achieve a final $\mathrm{Zn}$ concentration of 10 or $50 \mu \mathrm{mol} / \mathrm{L}$. Unsupplemented medium contained $1 \mu \mathrm{mol} / \mathrm{L} \mathrm{Zn}$. The time of transfer to serum-free medium after cell attachment to culture dishes was considered time 0 . Studies were performed after $24 \mathrm{~h}$ of culture in medium containing $\mathrm{Zn}$ concentrations as described.

Tritiated thymidine incorporation and DNA content. Isolated hepatocytes were plated in six-well dishes, adhered overnight as described above, and then transferred to serum-free medium 
supplemented with $0.2 \%$ albumin and either 1,10 , or $50 \mu \mathrm{mol} /$ L Zn. IGF-II (Lilly Research Laboratories, Indianapolis, IN) was added in some experiments to achieve a final concentration of $100 \mu \mathrm{g} / \mathrm{L}(100 \mathrm{ng} / \mathrm{mL})$. Methyl- ${ }^{3} \mathrm{H}$-thymidine $(\sim 80 \mathrm{Ci} / \mathrm{mmol}$, Amersham, Arlington Heights, IL) was added to the medium at a concentration of $1.5 \mathrm{mCi} / \mathrm{L}(1.5 \mu \mathrm{Ci} / \mathrm{mL})$, and cells were incubated for $24 \mathrm{~h}$. Medium was removed at $24 \mathrm{~h}$ and cells were washed twice with ice-cold PBS before precipitation with $10 \%$ trichloroacetic acid. Triplicate wells were harvested for scintillation counting and DNA determination by the diphenylamine reaction (9). In some experiments, cells were fixed in $4 \%$ paraformaldehyde, then exposed in situ to photographic emulsion (NTB-3 Nuclear Track Emulsion, Eastman Kodak Co., Rochester, NY) for determination of nuclear labeling index by autoradiography. Counterstaining with hematoxylin and eosin (Sigma Chemical Co., St. Louis, MO) was performed to identify cell types morphologically. Cuboid cells with round nuclei in cords or sheets were considered hepatocytes; other cells with oblong or stellate shapes or isolated nuclei were considered nonhepatocytes. Nuclear labeling index for hepatocytes and nonhepatocytes was determined by two investigators (S.F.T., K.K.B.) unaware of treatment conditions. Interobserver agreement was greater than $98 \%$.

RNA extraction and analysis. After removal of medium, cultured cells were harvested into a solution of $5 \mathrm{M}$ guanidine thiocyanate, $25 \mathrm{mM}$ sodium citrate, $0.5 \%$ sodium sarcosyl, and $100 \mathrm{mM} \beta$-mercaptoethanol, and total RNA was extracted according to the method of Chomczynski and Sacchi (10). RNA was quantified by UV absorbance at 260 and $280 \mathrm{~nm}$ and purity and integrity were assessed by agarose-gel electrophoresis with ethidium bromide staining. For slot blots, total cellular RNA was applied directly to nylon membranes with a slot-blot apparatus (Bio-Dot SF, Bio-Rad, Richmond, $\mathrm{CA}$ ) after denaturation in buffer containing $50 \%$ formamide, $6 \%$ formaldehyde, and 20 mM 3-[N-morpholino]propanesulfonic acid and cross-linked by irradiation with UV light (UV-Stratalinker, Stratagene, La Jolla, CA). For Northern blots, RNA samples were electrophoresed in agarose/formaldehyde gels and transferred overnight to nylon membranes by standard methods (11).

IGF-II mRNA was identified using a full-length ovine IGF-II cDNA obtained from T. E. Adams (12). All cDNA were labeled by random primer extension (kit from Boehringer-Mannheim, Mannheim, Germany) with 5-( $\left.\alpha^{32} \mathrm{P}\right)$-deoxycytidine triphosphate (Amersham) to a sp act of $\sim 10^{9} \mathrm{cpm} / \mu \mathrm{g}$. Blots were washed under high-stringency conditions $[0.015 \mathrm{M} \mathrm{NaCl}, 0.0015 \mathrm{M}$ sodium citrate, $\mathrm{pH} 7.0(0.1 \times \mathrm{SSC})$, and $0.1 \% \mathrm{SDS}$ at $\left.65^{\circ} \mathrm{C}\right](11)$. Blots were boiled and reprobed for 18S rRNA (probe kindly provided by V. Han, London, Ontario) to verify comparable loading. IGF-II was quantified by scanning densitometry of slot blots, with the IGF-II signal normalized to the $18 \mathrm{~S}$ rRNA signal intensity before statistical analyses.

Western ligand blotting. Western ligand blot analyses of IGFBP were performed by a modification of standard methods $(13,14)$. In brief, samples of medium were denatured at $100^{\circ} \mathrm{C}$ in buffer containing $0.06 \mathrm{M}$ Tris- $\mathrm{HCl}, 0.8 \% \mathrm{SDS}, 4 \%$ glycerol, and $0.004 \%$ bromophenol blue for $5 \mathrm{~min}$, then size fractionated on $8 \%$ SDSpolyacrylamide gels at $30 \mathrm{~V}$ for $20 \mathrm{~h}$. Proteins were electroblotted onto nitrocellulose membranes overnight at $50 \mathrm{~V}$, then blocked by washing in $0.15 \mathrm{M} \mathrm{NaCl}, 10 \mathrm{mM}$ Tris- $\mathrm{HCl}$ buffers containing sequentially $\mathrm{NaN}_{3}$, Nonidet P-40, BSA, and Tween 20 (Sigma Chemical Co.). The membranes were then incubated overnight with 200000 to $400000 \mathrm{cpm}$ of ${ }^{125}$ I-labeled IGF-II $(\sim 2000 \mathrm{Ci}$ / mmol, Amersham), and binding proteins were detected by autoradiography. IGFBP were presumptively identified by molecular weight and by comparison with known fetal sheep IGFBP profiles (15).

Biochemical assays. After $24 \mathrm{~h}$ in culture, aliquots of media were saved and dishes were rinsed in succession with solutions containing $0.9 \% \mathrm{NaCl}, 0.9 \% \mathrm{NaCl}$ with $0.1 \%$ albumin and 1 mM EDTA, then $0.9 \% \mathrm{NaCl}$ to remove residual medium. Cells were harvested by scraping and pelleted by centrifugation. All rinse solutions were aspirated from the cell pellet, then an aliquot was reserved for measurement of protein content by a modification of the Lowry method (16). Zinc content of the remaining cell pellet was measured by atomic absorption spectroscopy after ashing overnight in a low temperature asher (17). $\mathrm{Zn}$ in the medium was measured directly by atomic absorption spectroscopy with a Perkin-Elmer 2380 spectrophotometer (Perkin-Elmer Corp., Norwalk, CT) fitted with a single-slot burner head and a deuterium background correction lamp.

Statistical analyses. All assays were performed at least in duplicate, and the results from three to seven experiments were compared. Results are expressed as the mean \pm SD. Data from $\mathrm{Zn}$-supplemented dishes (10 and $50 \mu \mathrm{mol} / \mathrm{L} \mathrm{Zn)} \mathrm{were} \mathrm{compared}$ with data from control, unsupplemented dishes $(1 \mu \mathrm{mol} / \mathrm{L} \mathrm{Zn})$ by analysis of variance with a microcomputer statistical software package (SuperANOVA, Abacus Concepts, Berkeley, CA). Significance at $p<0.05$ was determined by the Scheffe's $S$ test for post hoc comparisons.

\section{RESULTS}

The concentration of $\mathrm{Zn}$ in unsupplemented medium (low $\mathrm{Zn})$ was $1.0 \pm 0.2 \mu \mathrm{mol} / \mathrm{L}(n=7)$. After $24 \mathrm{~h}$ of culture of liver cells in serum-free medium, $\mathrm{Zn}$ concentration in unsupplemented medium increased to $1.5 \pm 0.7 \mu \mathrm{mol} / \mathrm{L}(p=0.04)$. In all cultures initially supplemented with $\mathrm{Zn}$, the concentration of $\mathrm{Zn}$ in medium declined over $24 \mathrm{~h}$ from $10.8 \pm 1.2$ to $7.4 \pm 2.3$ $\mu \mathrm{mol} / \mathrm{L}$ and $45.3 \pm 9$ to $37.3 \pm 10.9 \mu \mathrm{mol} / \mathrm{L}$ (Fig. 1). Associated with the increase of $\mathrm{Zn}$ concentration in medium in low $\mathrm{Zn}$ cultures, cellular $\mathrm{Zn}$ and $\mathrm{Zn}$ /protein ratios in unsupplemented (low $\mathrm{Zn}$ ) dishes declined by $55 \pm 6$ and $48 \pm 6 \%$, respectively, after $24 \mathrm{~h}(n=3)$. Zn content of cell pellets was unchanged after $24 \mathrm{~h}$ in $10-\mu \mathrm{mol} / \mathrm{L}$ dishes and increased by $147 \pm 12 \%$ in $50-$ $\mu \mathrm{mol} / \mathrm{L}$ dishes, demonstrating uptake of $\mathrm{Zn}$ by the mixed liver cell population under these conditions. Therefore, after $24 \mathrm{~h}$ in culture in medium containing low $\mathrm{Zn}(1 \mu \mathrm{mol} / \mathrm{L})$ or supplemented to physiologic $(10 \mu \mathrm{mol} / \mathrm{L})$ or high $(50 \mu \mathrm{mol} / \mathrm{L}) \mathrm{Zn}$, the $\mathrm{Zn}$ content and $\mathrm{Zn} /$ protein ratios of cell pellets in supplemented cultures were approximately $150 \%$ and $200 \%$, respectively, of values from low $\mathrm{Zn}$ dishes (Fig. 2). Protein content of cell pellets decreases by $\sim 15 \%$ after $24 \mathrm{~h}$ of culture in serum-free medium but did not vary with $\mathrm{Zn}$ content of medium (Fig. 2, Table 1). Hepatocyte DNA content also did not differ after exposure to the varying $\mathrm{Zn}$ concentrations in medium (Table 1 ).

Supplementation of $\mathrm{Zn}$ in medium to 10 and $50 \mu \mathrm{mol} / \mathrm{L}$ decreased ${ }^{3} \mathrm{H}$-thymidine incorporation of cells in culture by 11

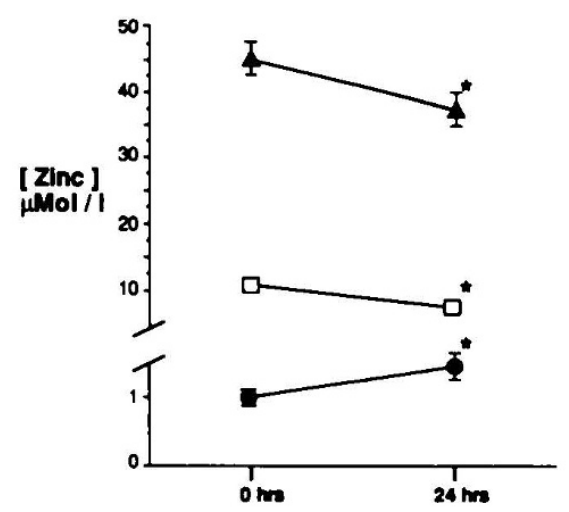

Fig. 1. Change in $\mathrm{Zn}$ concentration of medium conditioned by fetal liver cells over time in culture. Hepatocytes were transferred at $0 \mathrm{~h}$ to medium containing approximately 1,10 , or $50 \mu \mathrm{mol} / \mathrm{L} \mathrm{Zn}$, as described in Materials and Methods. Medium was removed after $24 \mathrm{~h}$ of incubation with hepatocytes in culture and assayed for $\mathrm{Zn}$ concentration as described. The results (mean \pm SEM) of four experiments assayed in duplicate are shown; note change in scale. ${ }^{*}, p<0.05$ compared with 0 h. 


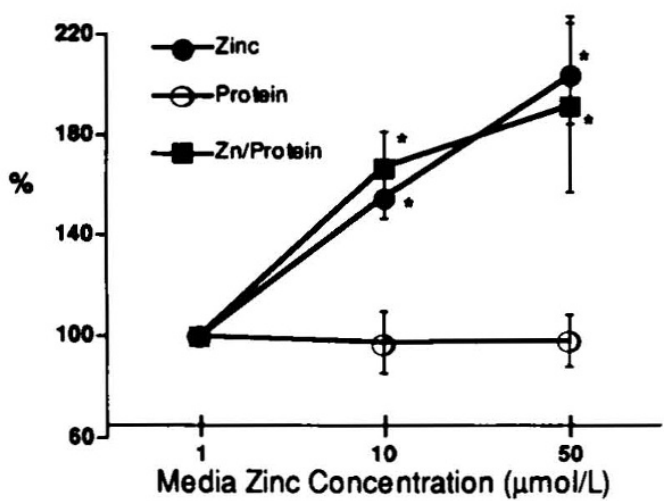

Fig. 2. $\mathrm{Zn}$ and protein contents and $\mathrm{Zn}$ /protein ratios of liver cell pellets after $24 \mathrm{~h}$ of culture in 1,10 , and $50 \mu \mathrm{mol} / \mathrm{L} \mathrm{Zn}$. Results are expressed as a percentage of the values obtained from cell pellets cultured in unsupplemented medium $(1 \mu \mathrm{mol} / \mathrm{L})$. The results of three experiments are shown. *, $p<0.05$ compared with $1-\mu \mathrm{mol} / \mathrm{L}$ dishes.

Table 1. Hepatocyte protein and DNA content after $24 \mathrm{~h}$ in culture with varying concentrations of $\mathrm{Zn}$ in medium

\begin{tabular}{ccc}
\hline $\begin{array}{c}\mathrm{Zn} \\
(\mu \mathrm{mol} / \mathrm{L})\end{array}$ & $\begin{array}{c}\text { Protein } \\
(\mathrm{mg} / \text { dish, } n=3)^{*}\end{array}$ & $\begin{array}{c}\text { DNA } \\
(\mu \mathrm{g} / \text { well, } n=6)^{*}\end{array}$ \\
\hline 1 & $324 \pm 61$ & $33 \pm 4.6$ \\
10 & $331 \pm 44$ & $33.1 \pm 5.1$ \\
50 & $356 \pm 67$ & $33.3 \pm 4.8$ \\
\hline
\end{tabular}

* $n=$ number of experiments.

\pm 1.4 and $13 \pm 2.3 \%$, respectively, compared with $1 \mu \mathrm{mol} / \mathrm{L} \mathrm{Zn}$ $(n=9, p=0.001)$. Because the decrease in ${ }^{3} \mathrm{H}$-thymidine incorporation after $\mathrm{Zn}$ supplementation was variable and did not differ between the two higher $\mathrm{Zn}$ treatments, DNA synthesis was examined by autoradiography to determine a nuclear labeling index by cell type. These primary fetal liver cell cultures, assessed morphologically, contain predominantly hepatocytes, accounting for $85-95 \%$ of cells, as well as nonhepatocytes (biliary cells, monocytes, fibroblasts, etc.) (8). Addition of $\mathrm{Zn}$ caused a progressive 2- to 3-fold decrease in the nuclear labeling index of cells identified as fetal hepatocytes, whereas the labeling index of nonhepatocytes increased almost 2-fold at $50 \mu \mathrm{mol} / \mathrm{L}$ compared with $1 \mu \mathrm{mol} / \mathrm{L} \mathrm{Zn} \mathrm{(Fig.} \mathrm{3).} \mathrm{Photomicrographs} \mathrm{demonstrating} \mathrm{the}$ differences in nuclear labeling of hepatocytes and nonhepatocytes in two separate experiments are shown in Figure 4. Panels $a$ and $b$ demonstrate appearance of nuclear labeling after culture in 1 $\mu \mathrm{mol} / \mathrm{L} \mathrm{Zn}$ and panels $c$ and $d$ after $24 \mathrm{~h}$ culture in $50 \mu \mathrm{mol} / \mathrm{L}$ $\mathrm{Zn}$.

Associated with decreased hepatocyte DNA synthesis, IGF-II mRNA abundance assessed by scanning densitometry of slot blots (corrected to $18 \mathrm{~S}$ rRNA) was decreased by $21 \pm 11 \%$ in hepatocytes cultured in $10 \mu \mathrm{mol} / \mathrm{L} \mathrm{Zn}$ and $31 \pm 12 \%$ in hepatocytes cultured in $50 \mu \mathrm{mol} / \mathrm{L} \mathrm{Zn}$ compared with hepatocytes maintained in $1 \mu \mathrm{mol} / \mathrm{L} \mathrm{Zn}(n=4)$. A representative Northern blot demonstrating this change in IGF-II mRNA from hepatocytes maintained in 1 and $50 \mu \mathrm{mol} / \mathrm{L} \mathrm{Zn}$ for $24 \mathrm{~h}$ is shown in Figure 5. There are seven known IGF-Il mRNA transcripts of varying size in the sheep (18), and culturing of fetal liver cells in the presence or absence of supplemental $\mathrm{Zn}$ did not appear to alter their relative abundance (Fig. 5). Addition of exogenous IGF-II $(100 \mu \mathrm{g} / \mathrm{L})$ to the culture medium increased DNA synthesis to $140 \%$ of unstimulated values; this increase was not affected by $\mathrm{Zn}$ supplementation.

We also examined the regulatory IGFBP produced by cultured cells over $24 \mathrm{~h}$ in three experiments. Medium conditioned by fetal liver cells in culture contained four species of IGFBP indicated by the arrows in Figure 6: IGFBP-3 migrating as a doublet, IGFBP-2, IGFBP-1, and IGFBP-4 (in descending order based on size). Increasing $\mathrm{Zn}$ content in medium did not alter

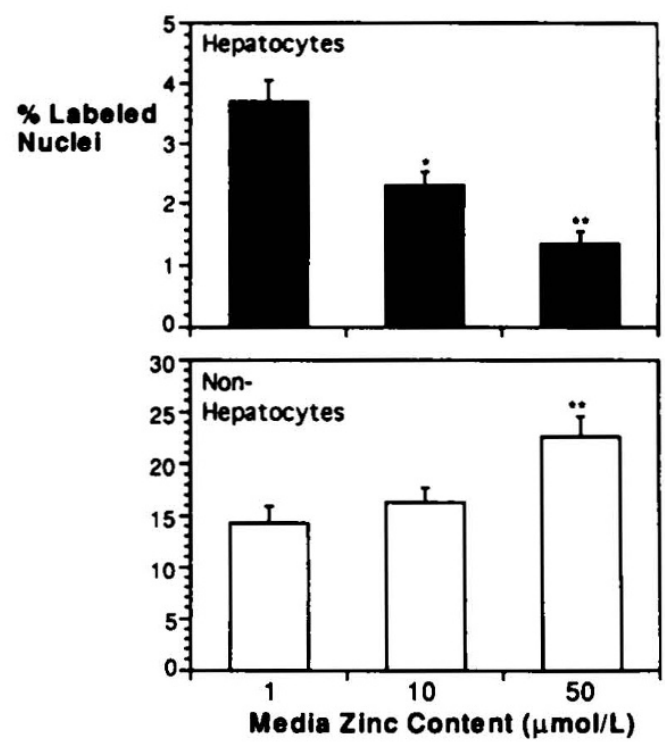

Fig. 3. Estimated nuclear labeling index of hepatocytes and nonhepatocytes after incubation with ${ }^{3} \mathrm{H}$-thymidine in medium containing either 1,10 , or $50 \mu \mathrm{mol} / \mathrm{L} \mathrm{Zn}$ as described in Materials and Methods. Cells were identified morphologically after staining in hematoxylin and eosin. ${ }^{*}, p<0.05$ compared with $1 \mu \mathrm{mol} / \mathrm{L} \mathrm{Zn;}{ }^{* *}, p<0.05$ compared with 1 and $10 \mu \mathrm{mol} / \mathrm{L} \mathrm{Zn}$.

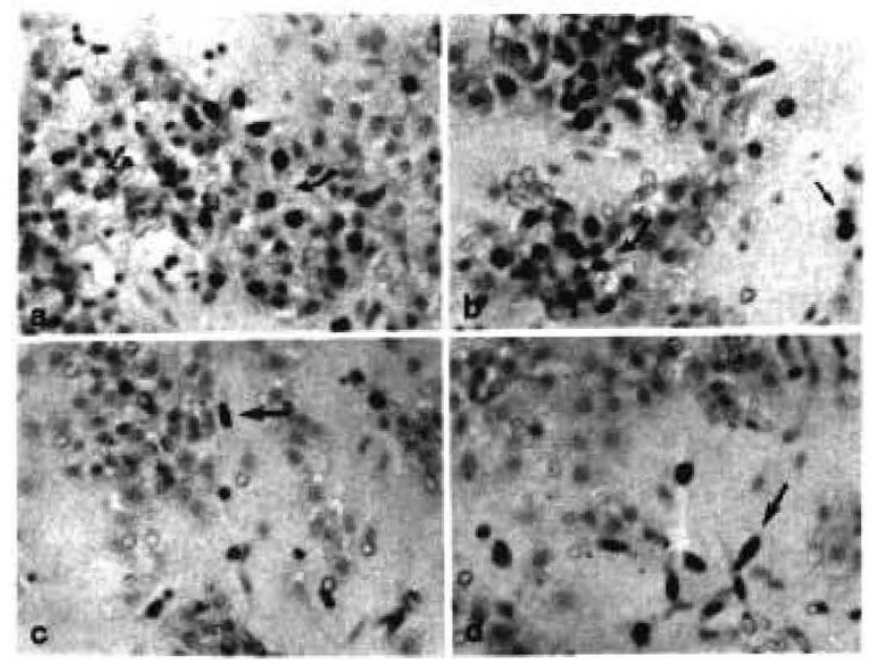

Fig. 4. Photomicrographs of liver cell cultures demonstrating nuclear labeling by ${ }^{3} \mathrm{H}$-thymidine after culture in medium containing basal levels $(1 \mu \mathrm{mol} / \mathrm{L})$ of $\mathrm{Zn}(a$ and $b)$ or supplemented to $50 \mu \mathrm{mol} / \mathrm{L} \mathrm{Zn}(c$ and d). Curved arrows denote hepatocytes, straight arrows nonhepatocytes. Two separate experiments are shown in $a$ and $c$ compared with $b$ and $d$. All panels are shown in magnification $\times 40$; counterstain is hematoxylin and eosin.

the IGFBP amount or distribution in conditioned medium (Fig. 6).

\section{DISCUSSION}

These experiments demonstrate that $\mathrm{Zn}$ in physiologic concentrations selectively decreases fetal hepatocyte DNA synthesis, whereas nonhepatocyte DNA synthesis is increased. Decreased DNA synthesis is accompanied by a decline in IGF-II mRNA abundance, which is likely to result in decreased IGF-II synthesis and may in part mediate the response observed. We chose to study concentrations of $\mathrm{Zn}$ that reflected the basal concentration in culture medium as supplied by the manufacturer, a physiologic concentration comparable to that determined in plasma from 


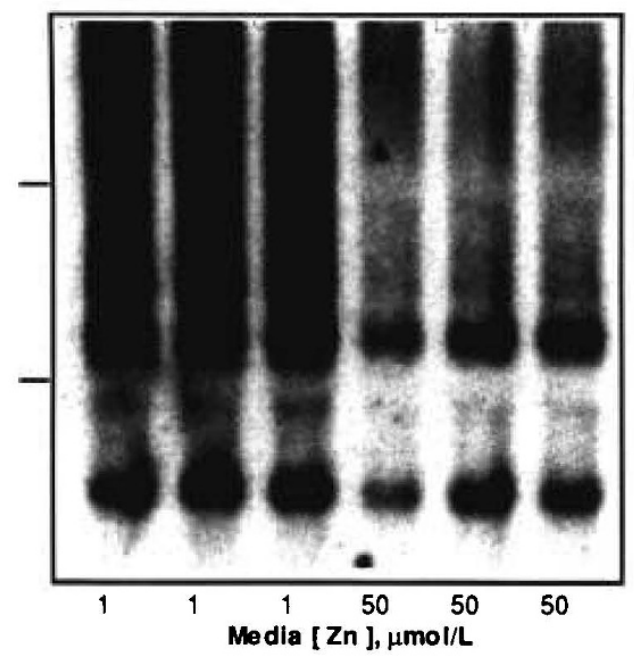

Fig. 5. A Northern blot of total RNA from fetal hepatocytes after 24 $\mathrm{h}$ of culture in medium with 1 or $50 \mu \mathrm{mol} / \mathrm{L} \mathrm{Zn}$, probed with a fulllength IGF-II cDNA as described. There are seven IGF-II mRNA transcripts identified. Although $50 \mu \mathrm{mol} / \mathrm{L} \mathrm{Zn}$ decrease total IGF-II mRNA abundance, the relative intensity of different transcripts is unchanged. Migration of $28 \mathrm{~S}$ and $18 \mathrm{~S}$ rRNA is indicated by the dashes.

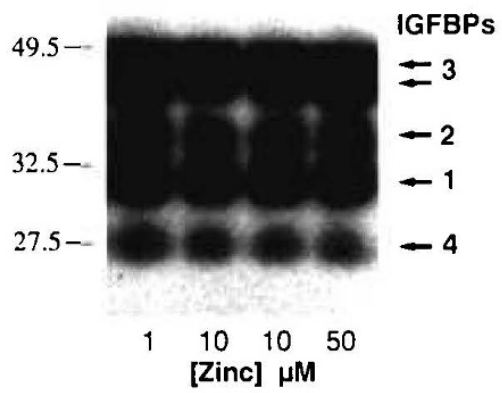

Fig. 6. A Western ligand blot of culture medium conditioned after incubation of fetal hepatocytes for $24 \mathrm{~h}$ in 1,10 , or $50 \mu \mathrm{mol} / \mathrm{L} \mathrm{Zn}$ showing no effect of $\mathrm{Zn}$ on IGFBP production by fetal hepatocytes. The blot was probed with ${ }^{125}$ I-labeled IGF-II to identify all IGFBP present, as indicated by the arrows. Note that IGFBP-3 migrates as a doublet. Molecular size markers are indicated on the left.

healthy lambs $(\sim 10 \mu \mathrm{mol} / \mathrm{L})(6)$, and a supraphysiologic concentration $(\sim 50 \mu \mathrm{mol} / \mathrm{L})$. Without $\mathrm{Zn}$ supplementation of serumfree medium, there is a decline in cultured fetal liver cell $\mathrm{Zn}$ content, and an increase in $\mathrm{Zn}$ concentration in the medium. Addition of $\mathrm{Zn}$ to the culture medium is associated with uptake of $\mathrm{Zn}$ by the fetal liver cells and a decline in $\mathrm{Zn}$ concentration in the medium. These responses are not associated with $\mathrm{Zn}$ toxicity to the cells: total DNA and protein content were not affected by $\mathrm{Zn}$ concentration in the medium, nor was production of a specific family of proteins, the IGFBP.

IGF-II is thought to mediate some of its growth-promoting effects via autocrine and paracrine mechanisms. There is abundant endogenous expression of IGF-II in cultured fetal hepatocytes and addition of exogenous IGF-II to primary cultures of fetal hepatocytes induces DNA synthesis (8). It is therefore possible that IGF-II is an autocrine growth factor for fetal hepatocytes. We hypothesize that $\mathrm{Zn}$ supplementation may act to decrease DNA synthesis in fetal hepatocytes in part through inhibiting expression of IGF-II, as seen by the decline in IGF-II mRNA abundance in response to increased $\mathrm{Zn}$ content in medium. $\mathrm{Zn}$ supplementation did not inhibit the proliferative response of fetal liver cells to exogenous IGF-II, suggesting that $\mathrm{Zn}$ was not directly interfering with the biologic actions of IGF-II.

Four IGFBP were identified in medium conditioned by cultured fetal liver cells. These have been presumptively identified as IGFBP-1, $-2,-3$, and -4 , based on their molecular weights and reports of known fetal sheep plasma IGFBP profiles (15). The IGFBP are important physiologic modulators of IGF-II activity, and production of IGFBP by the liver is in part nutritionally regulated (5). Therefore, factors that alter IGF-II expression might be expected to alter hepatocyte IGFBP production. However, $\mathrm{Zn}$ supplementation did not change the content of IGFBP seen in medium conditioned by fetal liver cells, suggesting that $\mathrm{Zn}$ is not directly involved in regulation of IGFBP production by fetal hepatocytes.

Uptake of $\mathrm{Zn}$ by liver cells has been studied previously by using adult hepatocytes in primary culture (19-21). Our observations of loss of $\mathrm{Zn}$ into the culture medium by hepatocytes with culture in unsupplemented medium are similar to those of Guzelian et al. (21) but differ from the work of Cousin's group, which demonstrated no loss of $\mathrm{Zn}$ from cells after up to $48 \mathrm{~h}$ in culture $(19,20)$. The loss of $\mathrm{Zn}$ by fetal hepatocytes maintained in primary culture in low $\mathrm{Zn}$ may reflect differences in $\mathrm{Zn}$ kinetics (uptake and utilization) in a population of fetal hepatocytes that maintains a substantial level of DNA synthesis compared with quiescent, nonproliferating adult hepatocytes. In addition, adult hepatocytes are adhered in culture in the presence of insulin, which could alter cellular $\mathrm{Zn}$ metabolism. Uptake of $\mathrm{Zn}$ in cultures supplemented to 10 and $50 \mu \mathrm{mol} / \mathrm{L}$ was similar to that observed in previous reports $(19,20)$.

Effects of $\mathrm{Zn}$ on DNA synthesis in general have been studied by using models of $\mathrm{Zn}$ deficiency to demonstrate a decrease in DNA synthesis. Our finding of decreased DNA synthesis in hepatocytes in response to supplemental $\mathrm{Zn}$ contrasts with these widely reported observations. Nonetheless, dietary $\mathrm{Zn}$ deficiency has been associated with increased DNA synthesis in at least one other tissue, the buccal mucosa in rabbits (22). It is difficult to compare other in vivo studies using dietary restriction of $\mathrm{Zn}$ with these direct, in vitro observations of the effects of provision of adequate $\mathrm{Zn}$ to proliferating fetal hepatocytes. In our experiments, provision of $\mathrm{Zn}$ in physiologic concentrations augmented DNA synthesis in nonhepatocytes, more in keeping with previous whole-animal studies. Also, careful analysis of studies in mice in which $\mathrm{Zn}$ deprivation was begun during pregnancy and continued throughout gestation demonstrated larger liver size in $\mathrm{Zn}$ deficient mice after birth than in $\mathrm{Zn}$-sufficient, pair-fed controls (23). Other organs were not similarly affected (23). It is likely that $\mathrm{Zn}$ may have direct effects on control of cellular growth through actions on specific DNA or RNA polymerases and other enzymes $(2,3)$ as well as indirect effects that may be mediated through regulation of transcription of important growth factors, such as the IGF. Because dietary manipulation of $\mathrm{Zn}$ is associated with altered food intake and changes in metabolic pathways that also influence, for example, IGF production [i.e. those involving glucose and insulin (6)], the results of dietary studies are impossible to compare directly with the experiments reported here.

We conclude that provision of $\mathrm{Zn}$ selectively decreases fetal hepatocyte proliferation in primary culture, whereas nonparenchymal cell growth is augmented. We speculate that some of this response may be caused by decreased expression of IGF-II, an autocrine growth factor for fetal hepatocytes. Production of the family of regulatory IGFBP by the fetal liver is not modulated by $\mathrm{Zn}$. These data suggest a complex role for $\mathrm{Zn}$ in fetal growth regulation, with different cell types capable of responding in diverse fashions to $\mathrm{Zn}$ supply.

Acknowledgments. The authors thank Jamie Westcott for her excellent technical assistance and Dr. William W. Hay, Jr. for access to some of the liver cells used in these experiments. We thank Lilly Research Laboratories (Indianapolis, IN) for the generous provision of IGF-II. 


\section{REFERENCES}

1. Hambidge KM, Casey CE, Krebs NF 1986 Zinc. In: Mertz W (ed) Trace Elements in Human and Animal Nutrition. Academic Press, New York, pp $1-137$

2. Vallee BL, Falchuk KH 1993 The biochemical basis of zinc physiology. Physio Rev 73:79-117

3. Chesters JK 1991 Trace element-gene interactions with particular reference to zinc. Proc Nutr Soc 50:123-129

4. DeChiara TM, Efstradiadis A, Robertson EJ 1990 A growth-deficiency phenotype in heterozygous mice carrying an insulin-like growth factor II gene disrupted by targeting. Nature 345:78-80

5. Drop SLS, Brinkman A, Kortleve DJ, Groffen CAH, Schuller A, Zwarthof EC 1991 The evolution of the insulin-like growth factor binding protein family. In: Spencer EM (ed) Modern Concepts of Insulin-like Growth Factors. Elsevier, New York, pp 311-328

6. Droke EA, Spears JW, Armstrong JD, Kegley EB, Simpson RB 1993 Dietary zinc affects serum concentrations of insulin and insulin-like growth factor 1 in growing lambs. J Nutr 123:13-19

7. Cossack ZT 1988 Effect of zinc level in the refeeding diet in previously starved rats on plasma somatomedin C levels. J Pediatr Gastroenterol Nutr 7:441445

8. Townsend SF, Thureen PJ, Hay Jr WW, Narkewicz MR 1993 Developmen of primary culture of ovine fetal hepatocytes for studies of amino acid metabolism and insulin-like growth factors. In Vitro Cell Dev Biol 29A:592596

9. Burton K 1955 A study of the conditions and mechanism of the diphenylamine reaction for the colorimetric estimation of deoxyribonucleic acid. Biochem J 62:315-323

10. Chomczynski P, Sacchi N 1987 Single-step method of RNA isolation by acid guanidinium thiocyanate-phenol-chloroform extraction. Anal Biochem 162:156-159

11. Selden RF 1987 Analysis of RNA by Northern hybridization. In: Ausubel FM Brent R, Kingston RE, Moore DD, Seidman JG, Smith JA, Struhl K (eds)
Current Protocols in Molecular Biology. John Wiley \& Sons, New York, pp 4.9.1-4.9.7

12. O'Mahoney J, Adams T 1989 Nucleotide sequence of an ovine insulin-like growth factor-II cDNA. Nucleic Acids Res 17:5392

13. Hossenlopp P, Seurin D, Segovia-Quinson B, Hardouin S, Binoux M 1986 Analysis of serum insulin-like growth factor binding proteins using Western blotting: use of the method for titration of the binding proteins and competitive binding studies. Anal Biochem 154:138-143

14. Winston SE, Fuller SA, Hurrell JGR 1989 Western blotting. In: Ausubel FM, Brent R, Kingston RE, Moore DD, Seidman JG, Smith JA, Struhl K (eds) Current Protocols in Molecular Biology. John Wiley \& Sons, New York, pp 10.8.1-10.8.6

15. Iwamoto H, Murray M, Chernausek S 1992 Effects of acute hypoxemia on insulin-like growth factors and their binding proteins in fetal sheep. Am J Physiol 263:E1151-E1156

16. Hartree EF 1972 Determination of protein: a modification of the Lowry method that gives a linear photometric response. Anal Biochem 48:122-127

17. Krebs NF, Hambidge KM, Jacobs MA, Rasbach JO 1985 The effects of a dietary zinc supplement during lactation on longitudinal changes in maternal zinc status and milk zinc concentrations. Am J Clin Nutr 41:560-570

18. O'Mahoney JV, Brandon MR, Adams TE 1991 Developmental and tissuespecific regulation of ovine insulin-like growth factor II (IGF-II) mRNA expression. Mol Cell Endocrinol 78:87-96

19. Pattison SE, Cousins RJ 1986 Kinetics of zinc uptake and exchange by primary cultures of rat hepatocytes. Am J Physiol 250:E677-E685

20. Schroeder JJ, Cousins RJ 1991 Maintenance of zinc-dependent hepatic functions in rat hepatocytes cultured in medium without added zinc. $J$ Nutr 121:844-853

21. Guzelian PS, O'Connor L, Fernandez S, Chan W, Giampetro P, Desnick R 1982 Rapid loss of $d$-aminolevulinic acid dehydratase activity in primary cultures of adult rat hepatocytes: a new model of zinc deficiency. Life Sci 31:1111-1116

22. Chen S-Y 1986 Autoradiographic study of cell proliferation in acanthotic buccal epithelium of Zn-deficient rabbits. Arch Oral Biol 31:535-539

23. Beach RS, Gershwin E, Hurley LS 1982 Reversibility of developmental retardation following murine fetal zinc deprivation. J Nutr 112:1169-1181 